\title{
The Juridical Analysis of Setting of Clinical Pharmacy Services in Hospitals
}

\author{
Daeng Agus Rizka Elok Auliyah ${ }^{1}$, Desak Made Nugrahartani ${ }^{2}$ Eva Kurniawati ${ }^{3}$, Adriano $^{4}$, \\ Mohammad Zamroni ${ }^{5}$ \\ ${ }^{1}$ Student Magister of Law, Faculty of Law, Hang Tuah University, Surabaya, ${ }^{2}$ Student Magister of Law, Faculty of \\ Law, Hang Tuah University, Surabaya, ${ }^{3}$ Student Magister of law, Faculty of Law, Hang Tuah University, Surabaya, \\ ${ }^{4}$ Assistant Professor, Faculty of Law, Hang Tuah University, Surabaya, ${ }^{5}$ Assistant Professor, Faculty of Law, Hang \\ Tuah University, Surabaya
}

\begin{abstract}
This research is based on statutory regulation relating to clinical pharmacy services in hospitals after the issuance of Minister of Health Regulation Number 3 of 2020 concerning Hospital Classification and Licensing (PMK 3 of 2020) which reaps various interpretations, especially clinical pharmacy services in hospitals. The methodology in this study used a normative juridical type and used four approaches, namely the statute approach, historical approach, comparative approach, and conceptual approach. Then a document study was carried out through tracing the sources of legal materials such as the Constitution, the Health Law, the Hospital Law, the Health Manpower Law and the statutory regulations relating to the rules for classifying pharmaceutical services in hospitals as well as studying reading sources related to the object of research. This research showed that there is actually a contradiction in norms between the Hospital Law, the Health Law, the Health Manpower Law and the Minister of Health Regulation Number 72 of 2016 concerning the Standard of Pharmaceutical Services in Hospitals which is the implementer of the Hospital Law and PMK 3 of 2020 concerning Hospital Classification and Licensing, where the lower statutory regulations may not conflict with the statutory regulations under it or known as the lex superior derogate legi inferiori principle.
\end{abstract}

Keywords: Juridical Analysis, Pharmaceutical Services, Clinical Pharmacy, Conflict of Norms

\section{Introduction}

Health Service Facility is a tool and/or place that iss used to carry out health service efforts, whether promotive, preventive, curative or rehabilitative carried out by the government, local governments, and/or the community. ${ }^{1}$ Health services will not be separated from pharmaceutical services, including Clinical Pharmacy services.

\section{Corresponding author:}

\section{Daeng Agus Rizka Elok Auliyah}

Student Magister of Law, Faculty of Law, Hang Tuah

University, Indonesia

Contact : Telp. +6281232029223 ;

Email-daengelok@gmail.com
Clinical Pharmacy is an extension of the role of the pharmacist profession that is not only oriented to drugs but also to patients and aims to improve the quality of drug therapy. Clinical pharmacy activities are centered on patients, cooperating and collaborating among professions with doctors, nurses in the health service team. ${ }^{2}$

Ironically, since the issuance of PMK 3 of 2020 concerning Hospital Classification and Licensing which is in Article 7 paragraph (2); "Health services provided by the Hospital at least consist of medical services and medical support, nursing and midwifery services, then non-medical services". Article 10 states that non-medical services consist of pharmaceutical services, laundry/ cleaner services, food/nutrition processing, maintenance of facilities and infrastructure and medical devices, information and communication, corpse handling, and 
other non-medical services.

The assumption that pharmacy personnel is nonmedical is because there is no direct interaction service with patients that raises pros and cons. This is because as a pharmacist there is a service called clinical pharmacy service that is a direct service provided by pharmacists to patients in order to minimize the risk of drug side effect, for patient safety purposes so that the patient's quality of life is guaranteed. However, the real role of pharmacists is marginalized by the hospital system where pharmacy services are localized in the logistics, dispensing, and administration sections. The many interpretations that have emerged since the enactment of PMK 3 of 2020 concerning the classification of pharmaceutical services will cause problems for pharmacist colleagues as those who carry out the role of pharmaceutical services in handling patients. So that there is no legal certainty in pharmaceutical services in hospitals so that it can lead to different interpretations from various parties and can influence the standard of pharmaceutical services in hospitals.

\section{Discussion}

\section{The Setting of Clinical Pharmacy Services in Hospitals based on principles of ius constitutum and ius constiduentum}

The word Pharmacy comes from the word Pharmacon which is Greek for poison or medicine. And the word Medicine/med·i·cine/ which means medicine science, drug, and medical science. Pharmacy is a health profession that includes activities in the fields of discovery, development, production, processing, compounding, drug information and drug distribution.

The legal basis for administering clinical pharmacy services in hospitals is the Decree of the Minister of Health Number 436.Menkes/SK/VI/1993 concerning Hospital Service Standard and Medical Service Standard that pharmaceutical services are an inseparable part of the hospital health service system.

The stipulation of Law Number 7 of 1963 concerning Pharmacy aims to establish basic provisions in the pharmacy sector in the context of implementing the Law Number 9 of 1960 concerning Health Principles. Then the Pharmacy Law was repealed and replaced with Law
Number 23 of 1992 concerning Health. Although the Pharmacy Law is repealed, the legal norms related to pharmacy have not all been replaced because until now the Pharmaceutical Bill is also unclear. Because, basically all laws contain legal principles which the rule of law is higher than the norms of the law. And the pharmacy work regulationis regulated in Government Regulation Number 51 of 2009 concerning Pharmaceutical Work as the material for implementing the Law on Health.

There has been a shift in the orientation of pharmaceutical services from managing drugs as a commodity to pharmaceutical care services. Pharmaceutical Care was known in 1990, and was only voiced in Indonesia in 2000. In practice, the responsibility for drug therapy is manifested in achieving positive results for patients. ${ }^{3}$

In the Law on Psychotropics, the Law on Narcotics and Minister of Health RegulationNumber 3 of 2015 concerning Circulation, Storage and Reporting of Narcotics, Psychotropics and Pharmacy Precursors, it is explained that the delivery of drugs of this class can only be submitted in the form of finished drugs and delivered, supervised directly by the pharmacist at the hospital pharmacy according to a doctor's prescription.

In Law Number 36 of 2009 concerning Health which applies now has a philosophy that Law Number 23 of 1992 is deemed incompatible with developments, demands and legal needs in community so it needs to be repealed and replaced. The new Health Law consists of 22 chapters with 205 articles and there are three times as many settings as the previous one. One of the articles that discusses pharmaceutical, states that pharmaceutical personnel must meet the provisions of the code of ethics, professional standards, rights of health service users, service standards and standard operating procedures.

In line with the development of the work of the pharmacist profession in hospital pharmacy installations, it is now regulated in the Minister of Health Regulation Number 72 of 2016 concerningthe Standard of Pharmaceutical Services in Hospitals(PMK 72 of 2016)with the aim of ensuring legal certainty for pharmaceutical personnel, protecting patients and community from irrational use of drugs in the context of patient safety. Pharmacists must be able to fulfill the patient's rights to avoid unwanted things, including 
lawsuits.

It can be seen from the history of setting regarding clinical pharmacy services in Indonesia, it was still very weak, therefore there is a need for clear and updated regulations in accordance with the present and the future.

Reporting from the European Associate of Hospital Pharmacis (EAHP) which was founded on March $6^{\text {th }}$, 1972 until now. Several countries have included the role of pharmacist services as medical services in hospitals. The hospital pharmacist is considered a reliable and unbiased partner for all matters relating to drugs and drug use. In the UK the regulation of hospital pharmacy practice is principally governed by three types of regulations:

1. The Drug Law, which regulates the production, distribution, import, export, sale and supply of medicinal products;

2. Drug Abuse Law, which controls the availability of drugs which is responsible for drug abuse and can be controlled;

3. Pharmaceutical Law, pharmacists must be registered at the Royal Pharmaceutical Society of Great Britain or the Pharmaceutical Society of Northern Ireland and follow a code of professional practice. ${ }^{4}$

Legal scienceis indispensable to support pharmacy in Indonesia from a side of the law or high regulation compared to only Government Regulation. Advance in Pharmacy Science is increasingly needed and considered to be very important for better future of communityhealth.

\section{Hospitals as Clinical Pharmacy Service Administrator Based on Hospital Law}

Law Number 44 of 2009 concerning Hospital was issued to complement the Health Law. According to the Law on Narcotics and Government Regulation 51 Pharmaceutical Work defines a hospital as a form of integrated health service that involves many professions including pharmacists. This legal basis places the legal status of pharmacy in various health service settings. According International Pharmaceutical Federation (FIP), every pharmacist's action has a liability that is accounted for scientifically and legally. ${ }^{5}$
Regulation of the Minister of Health is the implementer of Hospital Law concerning clinical pharmacy services

The ministerial regulation in Law Number 12 of 2011 concerning the Formation of Statutory Regulation is not regulated in the provisions of Article Paragraph (1). However, the existence of this type of regulation is regulated in Article 8 paragraph (1) of Law Number 12 of 2011, which confirms:

"Types of Statutory Regulation other than those referred to in Article 7 paragraph (1) include regulations stipulated by the People's Consultative Assembly, House of Representatives, Regional Representative Board, Supreme Court, Constitutional Court, Supreme Audit Board, Judicial Commission, Bank Indonesia, Ministers, agencies, institutions, or commissions the same level as established by law or by the government at the behest of the law, the Provincial Regional House of Representatives, Governor, Mayor/Regent/City/ RegencyRegional House of Representatives, Village Head or equivalent."

Although the provisions above do not explicitly state the types of statutory regulations in the form of "Ministerial Regulations”, but a phrase “... regulations stipulated by ... the minister ..." above, reflects the existence of a Ministerial Regulation as a type of statutory regulations. From this provision, it can be explained that ministerial regulationis born because of certain affairs in governmentnamely matters that have become the affairs of the ministry itself and affairs that have been determined by statutory regulation. However, not all ministries have the authority to form ministerial regulations, only the ministers who lead an institution have the right to issue ministerial regulations. ${ }^{6}$

The incompatibility of implementer of the Hospital Law occurred in PMK 3 of 2020 in the Article that it is stated that pharmaceutical services are categorized as non-medical services because there is no direct interaction between pharmacists and patients. Furthermore, how is the binding strength of the Minister of Health Regulation, then in Article 8 Paragraph (2) of Law Number 12 of 2011 affirms: "Statutory Regulation as referred to in paragraph (1) is recognized for its existence and has binding legal force as long as it is ordered by a higher level of Statutory Regulation or established based on authority." 
From the provisionsabove, there are two conditions for the regulations referred to in Article 8 paragraph (1) of Law Number 12/2011 has a binding force as statutory regulations, namely the first to be ordered by a higher statutory regulation; or establishedbased on authority.

Analysis of Norms in Regulation of the Minister of Health Number 3 of Year with Reference to Law Number 44 of 2009 concerning Hospitals.

In practice, it is often found that legal regulations lag behind concrete events, in the sense that there is no concrete event, so the existing regulations are often inadequate. Yohanes Sogar Simamora argues that legal principles are needed as a basis for the formation of legal rules and at the same time as a basis for solving legal problems that arise when the available legal rules are inadequate. $^{7}$

Referring to Satjipto Rahardjo's view that law is not what is written or said in the text, law is not only a rule but also behavior, law as text will be silent and only through human mediation it becomes alive, the text is just a zombie (living corpse) which is frightening, damaging, and disturbing the comfort of life and human life if it cannot be implemented and if it conflicts with the legal behavior of community. The law is seen not only as what is written, but also by the spirit and soul in it. The system of Indonesian legal norms forms a pyramid building, the prevailing legal norms are in a system that is tiered, multilayered, at the same time in groups. In the sense that legal norms are applicable, sourced and based on higher legal norms, and higher legal norms are applicable, sourced and based on higher legal norms. The building of this legal pyramid is to determine the degree of norms for each arrangement of higher legal norms and lower norms. The consequence of building a legal pyramid is that if there are conflicting legal/ regulatory norms (conflicting norms), then those that are declared applicable are those with a higher degree. In this context, the lex superior derogate legi inferioriprinciple of law (a law with a higher degree overrides the law of a lower degree) applies. In addition, the consequence of building the legal pyramid is the harmonization among the various layers of law (for example at the level of Laws), in the sense that among legal norms in layers/ level cannot conflict with each other. ${ }^{8}$
In this analysis, there is a Lex superior derogate legi inferiori principle, according to Hans Kelsen ${ }^{9}$, this principle is in accordance with the statutory regulations ladder theory or Stufenbau der Reschtsordnung which states that the binding power of a rule or norm lies in higher regulations or norms. Therefore the lower rules must not conflict with the higher regulations on which to base their binding power. If a lower rule conflicts with a higher rule, then the lower rule is overridden by a higher regulation. The application of the Lex Superior derogate legi inforiori principle in the preparation of a regulation is carried out so that in the future when the regulations have been agreed and applied there will be no disharmony in the laws.

a. Disharmony of laws caused by establishment is carried out by different institutions and often in different periods of time;

b. Officials authorized to establish statutory regulationchange either because they are limited by the term of office, shift of duty or replacement;

c. Weak coordination in the process of establishing statutory regulationthat involve various agencies and legal disciplines;

d. Public access to participate in the process of establishing statutory regulation is still limited;

e. There is no definite method and standard that binds all institutions authorized to make statutory regulation.

Disharmony of statutory regulations is a condition that needs to be avoided in the legal system because it can result in different interpretations in its implementation, the emergence of legal uncertainty and statutory regulation is not implemented effectively and efficiently as well as legal dysfunction, meaning that the law cannot function to provide behavioral guidelines to the community, social control, dispute resolution and as a means of social change in an orderly and regularly manner. ${ }^{10}$

The principle of Lex Superior derogate legi inforiori refers to the existing legislation hierarchy, in accordance with Law Number 12 of 2011 concerning the Establishment of Statutory Regulationthat the legal hierarchy system in Indonesia is: 
a. The 1945 Constitution of the Republic of Indonesia;

b. Decree of the People's Consultative Assembly;

c. Laws

d. Laws/Government Regulations in Lieu of Laws;

e. Government Regulations;

f. Presidential Decree;

g. Provincial Regulation;

h. and Regency/City Regulations.

So by looking at the hierarchical order, PMK 3 of 2020 should have its power under the Hospital Law while in this context the contents should not violate the contents or conflict with the contents of the Hospital Laws. A legal product is a system of norms made according to the higher and highest norms, namely the basic norms (Grundorm).

\section{Conclusion}

Based on the description that has been stated, it can be concluded that the setting of clinical pharmacy services was clear even though it was only a Minister of Health Regulation, only at the level of implementation in the field was lacking so that not many understand and thought that pharmacy in hospitals only focused on managerial. According to the analysis carried out, there was a conflict of norms (antinomy normen) due to the incompatibility of the regulations of the minister of health as the implementer of laws or regulations that were above then also between concrete practices and inconsistent regulations, resulting in many wrong interpretations.

\section{Limitation and Study Forward}

This study aims to analyze the setting of clinical pharmacy services according to the Hospital Law that is very different from PMK 3 of 2020. And this research needs to be continued because of conflicting norms in higher regulations. Meanwhile, PMK 3 of 2020 should be repealed and adhere to the previous regulations or legitimate for clinical pharmacy regulations which are higher than only PMK 72 of 2016, so that there will be no interpretation without direction and principles.

Ethical Clearance : Nil

Conflict of Interest : Nil

Source of Funding : Self Founding

Acknowledgement : Nil

\section{Reference}

1. Soekidjo Notoatmodjo, Etika dan Hukum Kesehatan, Rineka Cipta, Jakarta, 2010.

2. Retriyani et.al., Persepsi Dokter Dan Perawat Tentang Peran Apoteker Dalam Pelayanan Farmasi Klinik Di Rumah Sakit PKU Muhammadiyah Yogjakarta, UMY Yogjakarta, 2016.

3. Cipolle, R.J.,Strand, L., Morley, P.C.,Pharmaceutical Care Practice, McGraw Hill, New York, 1998.

4. European Association of Hospital Pharmacist, Walzegem 6 BE-9860 Oosterzele-Bal, April 2002.

5. Max Joseph Herman, Rini Susanti H, Selma Arsit Siahaan, Analysis of Pharmacy Practice by Pharmacist in Hospital Selting, Jurnal Kesehatan Masyarakat, No. 8, Volume 7, Maret 2013.

6. Tesano, Hierarkhisitas Kedudukan Peraturan Menteri dengan Peraturan Daerah Dalam Sistem Peraturan Perundang-Undangan Di Tinjau dari Undang-Undang Nomor 12 Tahun 2011, https:// media.neliti.com/media/publications/209793hirarkhisitas-kedudukan-peraturan- menter.pdf. Accesed on December $8^{\text {th }} 2020$, at 2.15 pm.

7. M.Hadi Subhan, Prinsip Hukum Kepailitan di Indonesia, Disertasi, Program Pascasarjana Universitas Airlangga, Surabaya, 2006.

8. Tanto Lailam, Konstruksi Pertentangan Norma Hukum dalam Skema Pengujian Undang-Undang, Jurnal Konstitusi, Vol. 11, No. 1, Yogjakarta, Maret, 2014.

9. Abintoro Prakoso, Pengantar Ilmu Hukum, LaksBang PRESSindo, Yogjakarta, 2007.

10. http://ditjenpp.kemenkumham.go.id/component/ content/article/100-hukum-tata- negaraperundangundangan/421-harmonisasi-peraturan-perundangundangan.pdfAccesed on Oct $20^{\text {th }} 2020$ at $4.55 \mathrm{am}$. 